\title{
New species of Fannia Robineau-Desvoidy, 1830 (Diptera: Fanniidae) from Nepal
}

\author{
Новый вид Fannia Robineau-Desvoidy, 1830 (Diptera: Fanniidae) \\ из Непала
}

\author{
Nikita E. Vikhrev \\ Никита Е. Вихрев
}

Zoological Museum of Moscow University, Bolshaya Nikitskaya 2, Moscow 125009, Russia. E-mail: nikita6510@ya.ru Зоологический музей, МГУ им. М.В. Ломоносова, Большая Никитская ул., 2, Москва 125009, Россия.

KEY WORDS: Fannia, Fanniidae, Diptera, Nepal.

КЛЮЧЕВЫЕ СЛОВА: Fannia, Fanniidae, Diptera, Непал.

ABSTRACT. Fannia medveda sp.n. is described from Nepal. The new Fannia is a sister-species of wellknown $F$. armata Meigen, 1826 . New faunistic records for $F$. armata are reported and its distribution in $\mathrm{E}$ Palaearctic is discussed.

РЕЗЮМЕ. Fannia medveda sp.n. описан из Непала. Новая Fannia близкородственна F. armata Meigen, 1826. Приведены новые находки $F$. armata, обсуждается распространение этого вида в восточной Палеарктике.

\section{Introduction}

It is a pleasure to describe an easily distinguished and nice species of Fannia Robineau-Desvoidy, 1830. Due to thorough work of the collector, Andrey Medvedev, the type series is large and some ecological data became known.

F. medveda sp.n. is a Himalayan sister-species of $F$. armata Meigen, 1826, a common European species with doubtful presence in East Palaearctic. I used this opportunity to specify and discussed distribution of F.armata in Asia.

\section{Material and methods}

The specimens listed are in the Zoological Museum of Moscow University (not indicated in text).

Localities are given as follows: country, region, geographical coordinates in the decimal degrees format.

The following generally accepted abbreviations for morphological structures are used: $f 1, t 1, f 2, t 2, f 3, t 3$ fore-, mid-, hind- femur or tibia respectively; $a c$ acrostichal setae; $d c$ - dorsocentral setae; $a, p, d, v-$ anterior, posterior, dorsal, ventral seta(e).

The abbreviation for the tarsi as tar followed by a pair of digits separated by a hyphen was proposed by Vikhrev [2011]: the first digit (1 to 3 ) gives the leg number and the second digit (1 to 5) gives the number of the tarsal segment. For example, tarl-4 - 4-th segment of fore tarsus; $\operatorname{tar} 3-1$ - hind basitarsus.

\section{Fannia armata Meigen, 1826}

Fig. 4.

MATERIAL. BELARUS, Vitebsk reg., Orsha env, Dnepr R, $54.543^{\circ} \mathrm{N} 30.463^{\circ} \mathrm{E}, \mathrm{N}$. Vikhrev, $11.06 .2017,10^{\top}$.

KAZAKHSTAN, Almaty reg.: M Almatinka R., $43.17^{\circ} \mathrm{N}$ $77.04^{\circ} \mathrm{E}, 1450 \mathrm{~m}$ asl, N. Vikhrev, 15-21.05.2016, $10^{\top}$; Kapchagay L. env, $43.7^{\circ} \mathrm{N} 77.2^{\circ} \mathrm{E}, \mathrm{N}$. Vikhrev, 22-28.05.2016, $10^{\top}$.

KYRGYZSTAN, Chaktal Range, Sary-Chelek L., $2000 \mathrm{~m}$ asl $\left(41.90^{\circ} \mathrm{N} 71.95^{\circ} \mathrm{E}\right)$, L. Zimina, 29.05.1952, $30^{\top} \mathrm{O}^{7}, 2$ 우; A. Zhelokhovtsev, 29.05.1952, $30^{\top} 0^{\top}, 1$ ㅇ․

RUSSIA: Altai Republic reg.: $25 \mathrm{~km}$ SE of Ulagan, Bashkaus R. valley $\left(50.53^{\circ} \mathrm{N} 88.20^{\circ} \mathrm{E}\right), 1500 \mathrm{~m}, \mathrm{~V}$. Sorokina, $10.06 .2005,10^{\top}$; Seminsky Pass, $51.05^{\circ} \mathrm{N} 85.59^{\circ} \mathrm{E}, 1650 \mathrm{~m}$ asl, N. Vikhrev, 27$30.06 .2016,10^{7}$; Chuvashia reg., Yadrin env., $55.88^{\circ} \mathrm{N} 46.29^{\circ} \mathrm{E}, \mathrm{N}$. Vikhrev, 13.07.2009, 107, 1; Crimea reg., Alushta env., Rybachie, $44.7-8^{\circ} \mathrm{N}$ 34.4-6 ${ }^{\circ} \mathrm{E}, \mathrm{N}$. Vikhrev, 18-25.04.2014, $20^{7} \mathrm{O}^{\mathrm{T}}$; Khakassia, Shira distr, Itkul Lake env., $600 \mathrm{~m}$ asl, $54.445^{\circ} \mathrm{N} 90.177^{\circ} \mathrm{E}, \mathrm{K}$. Tomkovich, 25-28.06.2011, 10 , 1; Krasnodar reg., Krinitsa env.,

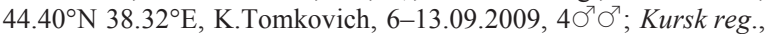
Streletskaya steppe, oak forest, $\left(51.565^{\circ} \mathrm{N} 36.085^{\circ} \mathrm{E}\right), \mathrm{N}$. Vikhrev, 12.08.2008, $30^{7} \sigma^{7}$, 2우; Moscow reg.: Dmitrov distr., Kostino env. $\left(56.31^{\circ} \mathrm{N} 37.75^{\circ} \mathrm{E}\right), \mathrm{N}$. Vikhrev, 20-28.06.2008, $50^{\top} \mathrm{O}^{\top}, 4$ 우우; 1.07.2009, $3 \mathrm{O}^{7} \mathrm{O}^{7}, 2$,

SERBIA, Stara Planina, $43.396^{\circ} \mathrm{N} 22.607^{\circ} \mathrm{E}, 1030 \mathrm{~m}$ asl, $1-$ 8.05.2015, N. Vikhrev, $20^{7} \sigma^{7}$.

TURKEY, Hatay prov., Arsuz $\left(36.41^{\circ} \mathrm{N} 35.88^{\circ} \mathrm{E}\right)$ env., N. Vikhrev, 13.04.2010, $10^{7}, 5$ 우요.

DISTRIBUTION. Widespread in Europe. Asian records: SE Kazakhstan; Kyrgyzstan; Russia: Altai-Sayan Mts; Turkey.

DISCUSSION. F. armata is a common European species. However the eastern limit of its distribution was not clear. According to https://fauna-eu.org database it is Central European Territory of Russia. Pont [1986] stated W Siberia

How to cite this article: Vikhrev N.E. 2018. New species of Fannia Robineau-Desvoidy, 1830 (Diptera: Fanniidae) from Nepal // Russian Entomol. J. Vol.27. No.2. P.207-209. doi: 10.15298/rusentj.27.2.12 


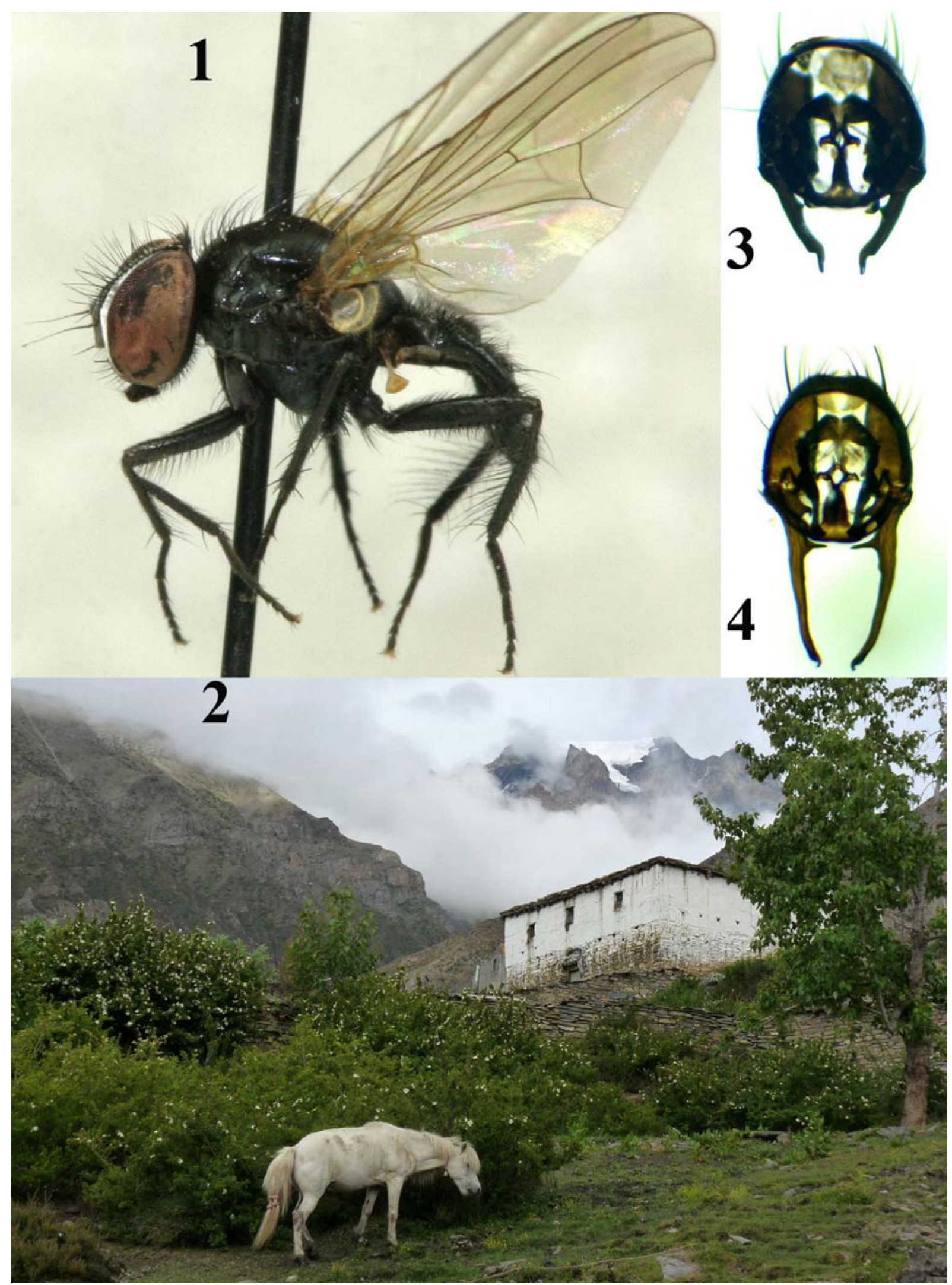

Figs 1-4. Fannia spp.: 1-3-F. medveda sp.n.; $4-F$. armata; 1 - Holotype, $\mathrm{O}^{7} ; 2$ - Muktinath, $3600 \mathrm{~m}$ asl, type locality (photo: A. Medvedev); 3-4 - male terminalia, internal view.

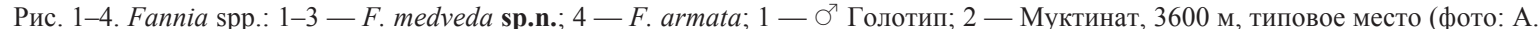
Медведева); 3-4 - терминалии самца, с внутренней стороны. 
but with "'?" mark. In Rozkosny et al. [1997] F. armata was stated as an Eurosiberian species. Wang et Wang [2006] reported a single Chinese record: Heilongjiang prov., Jingpo Lake $\left(44^{\circ} \mathrm{N} 129^{\circ} \mathrm{E}\right)$.

The material listed above includes only male specimens or females collected together with males, so identifications were always reliable. The records from Belarus, South European Territory of Russia and Asian Turkey are formally new but well predictable. The records from Central Asia show that F. armata is distributed in Tian Shan and Altai-Sayan Mts. If the record for Chinese Far East is correct it means that most probably $F$. armata is distributed all along S Siberia.

Another problem is the distributional borders between $F$. armata and its sister-species $F$. medveda sp.n. described below from Himalaya. The Tian Shan and Altai-Sayan Mts are separated from the Tibetan Plateau by the vast and lifeless Taklamakan and Gobi Deserts, but connected with it by the Pamir Mts in the west. Thus, the most interesting regions to specify the limits of distribution of these two species would be Gorno-Badakhshan region in Tajikistan and Jammu and Kashmir state in India.

\section{Fannia medveda sp.n.}

Figs 1-3.

MATERIAL. Holotype $0^{7}$, NEPAL, Mustang distr., Muktinath env., $28.82^{\circ} \mathrm{N} 83.86^{\circ} \mathrm{E}, 3600 \mathrm{~m}$ asl, A. Medvedev, 25-30.06.2017; Paratypes, $470^{7} 0^{7}, 5$ 웅, the same data.

DESCRIPTION. Male. Entirely black fly, body length: $4.6-5.3 \mathrm{~mm}$

Head. Eyes bare, distance between eye margins at middle of frons about half width of postpedicel. Fronto-orbital plates and parafacials whitish dusted. Fronto-orbital plates with 10 12 long inclinate setae all along the frons from antenna to ocellar triangle; reclinate seta absent. Postpedicel $2-2.5 \mathrm{x}$ as long as broad. Arista virtually almost bare.

Thorax with scutum shining black, pleura with thin grey dusting. Two rows of prst ac, prealar seta strong, $0.5 \mathrm{x}$ as long as posterior notopleural and with additional prealar setulae behind it. Proepimeral seta surrounded by 4-5 setulae. Wing hyaline, with brownish tint. Calypters yellowish-white, welldeveloped, lower one projecting beyond upper one. Haltere yellow.

Legs. $t 1$ with a row of 8-9 long (3-3.5x tibia width) fine $p v$ setae in apical 2/3. $f 2$ distinctly constricted in apical 1/4 . Chaetotaxy of $f 2$ : $a v$ surface with a row of about 8 strong setae in basal 3/4 and a dense brush of 20 short setulae in apical constricted quarter; base of femur with v spine (1-15x as long as femur width); $p$ and $p v$ surfaces each with dense row of fine long (longer than femur width) setae slightly curved at apex. $t 2$ remarkably thickened in apical $2 / 3$. Chaetotaxy of $t 2: v$ surface in thickened $2 / 3$ covered with setulae (as long as tibia width), these setulae are dense in basal half of thickened part of tibia and sparse in apical half; 3(4) ad setae in apical half and 1(2) short $p d$ seta(e) around middle. Base of tar2-1 with a dense brush of 15 short $v$ setulae. Hind coxa without seta on inner posterior margin. $f 3$ with a row of $8-10$ strong $a v$ setae in apical $2 / 3$ and with a brush of about 15 fine long $(1-1.5 \mathrm{x}$ as long as femur width) $p v$ to $p$ setulae in apical $1 / 3$. Chaetotaxy of $t 3: a v$ surface with a complete row of about 20 setae, the longest of them $3-5 \mathrm{x}$ as long as tibia width; $p d$ and $p$ surfaces each with a complete row of fine long ( $2 \mathrm{x}$ as long as tibia width) setae slightly curved at apex; 2 long fine curled $p v$ setae at apex; submedian and preapical $d$ setae straight, not curled and not elongated as in $F$. armata.

Abdomen grey dusted, with black triangular median mark on tergites $1+2$ to 4 . Male cerci almost 2 times shorter than in $F$. armata, internal tooth at base of cerci much smaller (Figs 3-4).

FEMALE. I uncluded five females collected together with males $F$. medveda sp.n. in type series. But I could not find reliable differences from females of $F$. armata.

ETYMOLOGY. An arbitrary combination of letters derived from the collector's surname Medvedev and implied to be a noun in apposition.

DIAGNOSIS. Similar to $F$. armata in male but the legs are much more setulose and the setulae are remarkably long, $\sigma^{7} \sigma^{7}$ of two species differs as follow:

1. $t 1$ with a row of $8-9$ long (3-3.5x tibia width) fine $p v$ setae in apical $2 / 3$. Base of tar $2-1$ with a dense brush of 15 short $v$ setulae which do not form toothlike crest. $f 3$ with $8-10$ $a v$ setae in apical $2 / 3$ and with a brush of about 15 fine long $(1-1.5 \mathrm{x}$ as long as femur width) $p v$ to $p$ setulae in apical $1 / 3$. $t 3$ with longest $a v$ setae $3-5 \mathrm{x}$ as long as tibia width, with complete rows of $p d$ and $p$ setae. Male terminalia as in Fig. 2 medveda sp.n.

- $t 1$ without submedian setae, though $p v$ setulae in apical half sometimes slightly elongate (at most as long as tibia width). Base of tar $2-1$ with a crest (small toothlike ventral process) consisting of 5-6 short setulae. $f 3$ with 4-5 av setae in apical $1 / 3$ and without long setulae on $p v$ or $p$ surfaces. $t 3$ with longest $a v$ setae $2 \mathrm{x}$ as long as tibia width, without $p$ setae and with complete $p d$ setae in apical half only. Male terminalia as in Fig. 3. ....... armata Meigen

ECOLOGY. F. medveda sp.n. was collected in anthropogenic landscape immediately under the ablation area of glaciers. According to Andrey Medvedev males were observed swarming above cow dung heaps at $1 \mathrm{~m}$ height.

\section{References}

Pont A.C. 1986. Family Muscidae // Soós A., Papp L. (eds.). Catalogue of Palaearctic Diptera. Vol.11. Budapest: Akadémia Kiadó. P.57-215.

Rozkošný R., Gregor F., Pont A.C. 1997. The European Fanniidae (Diptera) // Acta scientiarum naturalium Academiae scientiarum Bohemicae, Brno. Vol.31. P.1-80.

Vikhrev N. 2011. Review of the Palaearctic members of the Lispe tentaculata species-group (Diptera, Muscidae): revised key, synonymy and notes on ecology // ZooKeys. Vol.84. P.59-70.

Wang M.-F., Wang R.-R. 2006. A review of the hirticeps-group of Fannia Robineau-Desvoidy (Diptera: Fanniidae), with the description of one new species from China // Zootaxa. Vol.1295. P.61-68. 